DOI: http://dx.doi.org/10.18203/2320-1770.ijrcog20181021

Original Research Article

\title{
Re-laparotomy in OBG: a clinical study
}

\author{
Bhagyashree Bijjaragi, Amulya M. N.*
}

Department of Obstetrics and Gynecology, KIMS, Koppal, Karnataka, India

Received: 25 February 2018

Accepted: 07 March 2018

\section{*Correspondence:}

Dr. Amulya M. N.,

E-mail: dramulyamn@gmail.com

Copyright: (C) the author(s), publisher and licensee Medip Academy. This is an open-access article distributed under the terms of the Creative Commons Attribution Non-Commercial License, which permits unrestricted non-commercial use, distribution, and reproduction in any medium, provided the original work is properly cited.

\section{ABSTRACT}

Background: If laparotomy done within 60 days of primary surgery for the original disease it is called re-laparotomy. Aim of this study was to determine the risk factors causing re-laparotomy, the indications, management and outcomes of re-laparotomy.

Methods: The study was conducted in the department of Obstetrics and Gynaecology, Vijayanagar Institute of Medical Sciences Hospital, Bellary, Karnataka. It is a 2 year prospective observational study of all the patients with re-laparotomy following operation done for obstetric or gynaecological indications.

Results: Total 4105 patients underwent major surgery in two years between October 2013 to September 2015. Relaparotomy was done in 10 cases. The incidence of re-laparotomy was $0.25 \%$ which is mainly for subacute intestinal obstruction, intraperitoneal haemorrhage, burst abdomen, PPH, rectus sheath hematoma.

Conclusions: Hemorrhage, burst abdomen, infections are the main reasons for re-laparotomy after obstetric and gynaecological surgeries. Though the incidence of re-laparotomy is low and the outcome is favourable, several measures must be undertaken to prevent re-laparotomy such as careful surgical technique, meticulous hemostasis and strict asepsis should be maintained.

Keywords: Burst abdomen, Hemorrhage, Re-laparotomy

\section{INTRODUCTION}

Re-laparotomy is original Greek word with three components re-repeated, Laparo-stomach and tomie-cut. If laparotomy done within 60 days of primary surgery for the original disease it is called re-laparotomy. Early relaparotomy is one that is done, within 21 days of the primary surgery. If the laparotomy is done which is planable, repeated and multiphasic to complete the primary surgery is not considered as re-laparotomy. It is a difficult decision requiring good clinical judgement. Even some times inappropriate decision may be deleterious to the patient leading to increased morbidity and mortality. Increasing trends in caesarean sections performing surgeries at the peripheral centres where non availability blood bank facilities, intensive care units still increases the complications leading to re-laparotomy. ${ }^{1}$ Caesarean section $(\mathrm{C} / \mathrm{S})$ is the most common obstetric operation carried out in daily obstetric practice and the incidence has shown a dramatic increase over the last years. With the improvement of operative technologies, anesthesia coverage, blood transfusion facilities and safety of Caesarean section have increased considerably. Still it is a major operation and is associated with certain risk and complication. $^{2}$

Now a day's with the rising trend of caesarean section in peripheral hospitals in our country the postoperative complications are also gradually increasing. ${ }^{3}$

Complications following caesarean section are higher than that of vaginal delivery. This depends on the surgical 
technique, institutional facilities and also the indication of surgery. Re-laparotomy following caesarean section is considered in the event of a near miss maternal mortality. ${ }^{4}$ The decision to operate and the surgery itself must be performed by senior and experienced surgeons. The selection of the patients to undergo this relaparotomy must be properly chosen so that they benefit from the surgery. If not then the situation may be deleterious as there is a high risk of mortality in such cases. An early identification of the complication of the previous surgery can lead to an early diagnosis and treatment so that the morbidity and mortality is reduced. ${ }^{5}$

The objective of this study is to know the indications, risk factors, procedure undertaken during re-laparotomy and its outcome and how to prevent need of re-laparotomy.

\section{METHODS}

This is a prospective study conducted at dept. of OBG VIMS Ballari, Karnataka. All the patients who were operated at our hospital for any obstetric or gynaecological cause or operated outside and referred to our hospital thereafter are included in this study for two years between October 2013 to September 2015. These patients were observed for the development of wound complications during their stay in the hospital. Those patients who developed wound complications that required re-laparotomy were included in the study.

\section{Inclusion criteria}

- Patients who underwent primary surgery within the hospital or outside and referred thereafter.

- Patients following any gynecological/obstetrical surgery which gave rise to complication.

- Time interval between the occurrence of complication between 0-60 days from the date of primary surgery.

\section{Exclusion criteria}

- Time interval more than 60 days following primary surgery.

\section{RESULTS}

There were total 10 cases who underwent re-laparotomy out of 4105 major obstetric and gynaecological surgeries. Incidence of re-laparotomy was $0.25 \%$.

In 8 patients (80\%) primary surgery done was LSCS on emergency basis while 2 patients $(20 \%)$ had elective surgery one being abdominal anterior sling operation for uterovaginal prolapse and other being staging laparotomy for ovarian carcinoma.

Major indication (Table 1) for re-laparotomy in our study was PPH, followed by burst abdomen and rectus sheath hematoma.

Table 1: Nature of complications among the patients.

\begin{tabular}{|lll|}
\hline Nature of complication & Frequency & Percentage \\
\hline Burst abdomen & 2 & 20 \\
\hline Peritoneal hemorrhage & 1 & 10 \\
\hline Rectus sheath hematoma & 2 & 20 \\
\hline $\begin{array}{l}\text { Subacute intestinal } \\
\text { obstruction }\end{array}$ & 1 & 10 \\
\hline $\begin{array}{l}\text { Post partum hemorrhage } \\
\text { Cecal perforation with }\end{array}$ & 3 & 30 \\
\hline
\end{tabular}

All the cases requiring re-laparotomy were analysed by co-relating (Table 2) with indication for primary surgery and predisposing factors for re-laparotomy. Indication for primary surgery per say did not appear to contributory factor in re-laparotomy. Major predisposing factor for relaparotomy was atonic PPH, insecure knots and post operative abdominal distension.

Table 2: Correlation of primary surgery with indication and predisposing factors for re-laparotomy.

\begin{tabular}{|llll|}
\hline $\begin{array}{l}\text { Indication of re-laparotomy } \\
\text { Burst abdomen (no-2) }\end{array}$ & $\begin{array}{l}\text { Indication of primary surgery } \\
\text { Emergency LSCS for Obstructed labour }\end{array}$ & $\begin{array}{l}\text { No of patients } \\
\text { undergoing } \\
\text { primary surgery }\end{array}$ & $\begin{array}{l}\text { Predisposing factors } \\
\text { for re-laparotomy }\end{array}$ \\
\hline $\begin{array}{l}\text { Peritoneal hemorrhage (no-1) } \\
\text { Rectus sheath hematoma } \\
\text { (no-2) }\end{array}$ & $\begin{array}{l}\text { Staging laparotomy for ovarian carcinoma } \\
\text { LSCS done outside, indication not known }\end{array}$ & $\begin{array}{l}\text { Abdominal distension } \\
\text { post operatively (100\%) }\end{array}$ \\
\hline $\begin{array}{l}\text { Subacute intestinal obstruction } \\
\text { (no-1) }\end{array}$ & $\begin{array}{l}\text { Erevious LSCS } \\
\text { Anterior sling operation for nalliparous } \\
\text { prolapsed }\end{array}$ & $1(50 \%)$ & insecure knots $(100 \%)$ \\
\hline $\begin{array}{l}\text { Post partum hemorrhage (no- } \\
3)\end{array}$ & $\begin{array}{l}\text { Placenta previa } \\
\text { CPD }\end{array}$ & $1(100 \%)$ \\
\hline $\begin{array}{l}\text { Cecal perforation with sepsis } \\
\text { (no-1) }\end{array}$ & Previous LSCS with scar tenderness & $1(100 \%)$ & $\begin{array}{l}\text { Mersilene tape } \\
\text { displacement(100\%) }\end{array}$ \\
\hline
\end{tabular}


Table 3: Procedures performed during re-laparotomy.

\begin{tabular}{|lll|}
\hline Indication of re-laparotomy & Procedure performed & $\begin{array}{l}\text { No of cases } \\
\text { undergoing procedure }\end{array}$ \\
\hline Burst abdomen & Tension band wiring with secondary suturing & $2(20 \%)$ \\
\hline Peritoneal hemorrhage & Hemoperitonium drainage and ligature of bleeder & $1(10 \%)$ \\
\hline Rectus sheath hematoma & Exploration of hematoma with ligation of bleeder & $2(20 \%)$ \\
\hline Subacute intestinal obstruction & Release of obstruction by removing mersilene tape & $1(10 \%)$ \\
\hline \multirow{2}{*}{ Post partum hemorrhage } & Compression suture alone & $1(10 \%)$ \\
\hline Cecal perforation with sepsis & Compression suture with internal iliac artery ligation & $1(10 \%)$ \\
\cline { 2 - 3 } & Hysterectomy & $1(10 \%)$ \\
\hline
\end{tabular}

Cases were also analysed (Table 3) for the procedure performed during re-laparotomy. Increased morbidity is seen in patients with re-laparotomy with prolonged hospital stay, need for blood transfusion and increased incidence of post operative infection. One patient died due to sepsis secondary to cecal perforation.

\section{DISCUSSION}

Complications inevitable in surgery. In some circumstances, they may call for a re-laparotomy, requiring the patient to go back to the operating room. Caesarean section is a major abdominal operation with it's attendant complications to the mother including hemorrhage, infection and injury to other organs. In day to day obstetric practice we have to deal with post caesarean complications associated with maternal morbidity and mortality. The goal of RL is to manage complications of the previous surgery, prevent intraabdominal infection or sepsis, maintain hemostasis and carry out delayed curative surgery. ${ }^{6}$

During our study period, there were a total of 4105 major operations and 10 cases required re-laporotomy following primary operation $(0.25 \%)$.

Total of 3922 were number caesarean, number of relaparotomy after caesarean were $8(0.20 \%)$. According to Levin et al. and study by Gedikbasi as cited by Ahmed Khan NB et al, the rate of re-laparotomy after caesarean was $0.2 \%$ and $0.12 \%$ respectively. ${ }^{4}$ In study by Raagab AE, incidence was $1.04 \% .^{7}$ The rate of re-laparotomy following caesarean section in our study was comparable to the other studies quoted. The majority of previous studies reported a rate of relaparotomy ranging between $0.2 \%-0.7 \% .^{8-10}$

The incidence of re-laparotomy after gynaecological operations were $1.09 \%$. It is comparable with study done by Shyamal D et al $(0.77 \%) .{ }^{11}$ The higher incidence of relaparotomy after gynaecological surgery may be due to old age of women with associated complications like malignancy and severe degree of endometriosis.
For re-laparotomies, mortality clusters around digestive, urologic, trauma with regards to initial operations. However obstetrical and gynaecological interventions are not always safe in these terms either. ${ }^{6}$ Present study revealed an overall mortality rate of $10 \%$ for cases undergoing re-laparotomies which is comparable with study done by Dasgupta $S$ et al. ${ }^{11}$ In present study, 1 case ending up with mortality had an infectious component of complication. Local infectious problems such as perforation of the colon must be handled meticulously and in co-operation with infectious diseases discipline. Conditions involving other organs such as pneumonia should not be ignored to eliminate infectious foci effectively. It can be inferred that the development of systemic sepsis, systemic inflammatory response syndrome, and multiple organ failure maintain a high rate of mortality after re-laparotomies despite the advances in critical care, surgical technique and antibiotics. ${ }^{6}$

Caesarean section on demand has become an increasingly common option for obstetrical patients recently. However, physicians should be mindful of and inform the patient about the complications, mortality and morbidity rates associated with the caesarean delivery in comparison to vaginal delivery. The CS procedure should be performed selectively for appropriate and necessary cases. It has been suggested that the indications for CS are often for social or inappropriate reasons. The World Health Organization (WHO) recommends that the CS rate should no higher than $15 \%$. Another factor that would decrease the rate of CS is encouragement of vaginal birth after previous caesarean section. ${ }^{6}$

Securing hemostasis is must for a safe and successful surgery. Obstetricians should use blunt dissection of subcutaneous tissue and unipolar coagulation after delivery of the infant. ${ }^{6}$ More than $50 \%$ of cases in our study underwent re-laparotomy due to complications related to haemorrhage.

Bleeding can occur from hypogastric, epigastric or uterine arteries or even the uterine incision. ${ }^{2}$ In case of hysterectomy failure to ligate securely a significant 
bleeding vessel, bleeding from vaginal cuff, and slippage of ligature or avulsion of tissue before or after clamping can be the cause of haemorrhage. ${ }^{12}$ Bleeding secondary to uterine atony is preventable by adopting active management of the third stage of labor in women with identifiable risk factors for uterine atony by either rectal misoprostol or oxytocin infusion. ${ }^{13}$

In present study Bleeding into the abdomen (10\%), post partum haemorrhage (30\%), rectus sheath hematoma $(20 \%)$. It is comparable to the study done by IP Alam et al. ${ }^{3}$ In study by Seal SL et al post-partum hemorrhage $(42.4 \%)$ and rectus sheath hematoma $(27.3 \%)$ were the leading causes for relaparotomy. ${ }^{9}$

It is essential to achieve proper hemostasis to ensure a safe and successful surgery. It is important to be careful about bleeding during transverse cutting and suturing of lateral extensions of rectus sheath. ${ }^{6}$ Bleeding points on under surface of rectus sheath should always be checked and secured to prevent rectus sheath hematoma. ${ }^{14}$

In study by Levin et al, as cited by Ahmed Khan NB et al the main indication for re-laparotomy was hemodynamic instability due to suspected intra-abdominal bleeding or uncontrolled $\mathrm{PPH}^{4}$ Bleeding secondary to atony or placenta previa are unpreventable situations, but complications of bleeding into the abdomen or hematoma formation, depend on the surgeon's, surgical techniques and tissue factor. ${ }^{6}$ Other indications for re-laparotomy in our study were subacute intestinal obstruction (10\%), burst abdomen (20\%) and peritonitis (10\%) which was comparable to study done by Fazari $\mathrm{AB}$ et al. ${ }^{15}$ It was concluded that best possible closure technique includes the following: a mass closure (compared to layer closure), a simple running suturing technique, use of absorbable monofilament suture material and suture length-to-wound length ratio of $4: 1 .^{6}$ Compliance with these recommendations, along with careful manipulation and enrolment of experienced staff in re-laparotomy cases, may yield better outcomes with decreased incidence of re-laparotomy. In our study, one fatal case had history of cecal perforation. This can be a source for peritonitis and sepsis, therefore attention must be paid not to damage other abdominal organs during surgery. Khan et al reported a case fatality rate of $18.5 \% .^{4} \mathrm{~A}$ rate of $12.76 \%$ and $15.38 \%$ were reported in two studies from India, while no deaths were encountered in the study done by Lurie et al. ${ }^{1,11,16}$ This wide variation in incidence of maternal mortality reported in different studies is due to variable availability of safe procedure, skilled personnel, adequate blood components, facilities for rapid transfer of complicated cases, close monitoring and timely decision for intervention.

\section{CONCLUSION}

Re-laparotomy is rare condition with limited likelihood of prevention in surgical practice of obstetrics and gynaecology. Patients with previous LSCS, atonic uterus and post operative abdominal distension are more likely to be at risk of re-laparotomy. If adequate hemostasis is achieved at the time of primary surgery considerable number of re-laparotomies might be avoided. Infectious complications like colon perforation have significantly higher rate of mortality. These findings must be taken into account at the time of decision making and counselling the patient before re-laparotomy is performed.

\section{Funding: No funding sources}

Conflict of interest: None declared

Ethical approval: The study was approved by the Institutional Ethics Committee

\section{REFERENCES}

1. Thombarapu U, Kodey PD, Koneru G. Retrospective study of relaparotomy in department of obstetrics, gynaecology and family planning in, rural tertiary care hospital, Andhra Pradesh, India. Int J Med Res Health Sci. 2015;4(3):582-6.

2. Salam R, Sabera S, Farhna D, Sama A. Relaparotomy after Caesarean Section in Tertiary Referral Teaching Hospital of Bangladesh. Bangladesh J Obstet Gynaecol. 2012;24:39.

3. Alam IP, Mahabuba, SR Das.Relaparotomy in Obstetrics and Gynaecology Department of Faridpur Medical College Hospital - Experience in One Year. Faridpur Med Coll J. 2012;7(2).

4. Khan NB, Kolasseri SS. Relaparotomy after caesarean section: an analysis of the risk factors, indications and outcome. Int $\mathrm{J}$ Reprod Contracept Obstet Gynecol. 2015 Jun;4(3):575-80.

5. Unalp HR, Kamer E, Kar H, Bal A, Peserkoy M, Onal MA. Urgent abdominal re-exploration. World J Emerg Surg. 2006;1:10.

6. Sak ME, Turgut A, Evsen MS, Soydinc HE, Ozler A, Sak $S$ et al. Re-laparotomy after initial surgery in obstetric and gynecologic operations: analysis of 113 cases. Ginekol Pol. 2012;83:429-32.

7. Raagab AE, Mesbah YH, Brakat RI, Zayed AA, Alsaammani MA. Re-laparotomy after cesarean section: risk, indications and management options. Med Arch. 2014 Feb;68(1):41.

8. Levin I, Rapaport AS, Satzer L, Maslovitz S, Lessing JB, Almog B. Risk factors for relaparotomy after cesarean delivery. Int J Gynaecol Obstet. 2012 Nov; 119(2):163-5.

9. Seal SL, Kamilya G, Bhattacharya SK, Mukherji J, Bhattacharya AR. Relaparotomy after caesarean delivery: experience from an Indian teaching hospital. J Obstet Gynaecol Res. 2007;33(6):804-9.

10. Seffah JD. Re-laparotomy after Cesarean section. Int J Gynecol Obstet. 2005;88(3):253-7.

11. Shyamal D, Pratim SP, Aradhana K, Partha M, Kirti M, Subhankar D. Early re-operations after gynecological and obstetrical surgery-a five years. J Obstet Gynecol India. 2010 Dec;60(6):507-10. 
12. Falcone T, Stovall G. In: Berek JS, Berek DL. Berek and Novak's Gynecology.15th ed. New Delhi: Wolter Kluwer;2013:831.

13. Badejoko OO, Ijarotimi AO, Awowole IO, Loto OM, Badejoko BO, Olaiya DS et al. Adjunctive rectal misoprostol versus oxytocin infusion for prevention of postpartum hemorrhage in women at risk: a randomized controlled trial. J Obstet Gynaecol Res. 2012 Nov;38(11):1294-1301.

14. Biswas SP, Halder S, Shirin FB. Indications and outcome of relaparotomy after cesarean section. Bang Med J (Khulna). 2012;45:19-23.
15. Fazari AB, Eldeen NS, Mohammed W, Muror M, Gailii E. Re-laparotomy after caesarean section at omdurman maternity hospital-Khartoum, Sudan. Open J Obstet Gynecol. 2015 Jul;5(08):448-54.

16. Lurie S, Sadan O, Golan A. Re-laparotomy after cesarean section. Eur J Obstet Gynecol Reprod Biol. 2007 Oct 1;134(2):184-7.

Cite this article as: Bijjaragi B, Amulya MN. Relaparotomy in OBG: a clinical study. Int J Reprod Contracept Obstet Gynecol 2018;7:1367-71. 